\title{
Cost and Return Analysis of Cassava Flour (Lafun) Production Among the Women of Osun State, Nigeria
}

\author{
Ganiyu Muibat Omolara ${ }^{1}$, Alabi Afusat Adunni ${ }^{1}$, Abiodun Olusola Omotayo ${ }^{2, *}$ \\ ${ }^{1}$ Department of Agricultural Economics, Faculty of Agriculture, Ladoke Akintola University of Technology, Ogbomoso, Nigeria \\ ${ }^{2}$ Department of Agricultural Economics and Extension, North West University, School of Agricultural Sciences, Mmabatho, South Africa
}

\section{Email address:}

omotayoabiodun777@gmail.com (A. O. Omotayo)

${ }^{*}$ Corresponding author

\section{To cite this article:}

Ganiyu Muibat Omolara, Alabi Afusat Adunni, Abiodun Olusola Omotayo. Cost and Return Analysis of Cassava Flour (Lafun) Production Among the Women of Osun State, Nigeria. Science Research. Vol. 5, No. 5, 2017, pp. 72-77. doi: 10.11648/j.sr.20170505.12

Received: June 7, 2017; Accepted: July 14, 2017; Published: November 28, 2017

\begin{abstract}
Recent hike in food prices in Nigeria has led to increased food insecurity among rural and urban dwellers. Rural households who are majorly farmers are faced with low income generation from farm produce. This study examined the economic analysis of cassava flour production among women in Boripe Local Government Area of Osun state. Primary data were collected through a well structured questionnaire supplemented with oral interview and a multi-stage sampling technique was adopted in selecting 146 respondents. Data were subjected to descriptive statistics, gross margin technique to estimate the profitability of cassava flour production. Ordinary least square regression model was used to analyze determinants of total revenue generated from cassava flour production enterprise. Results obtained showed that almost all cassava processors have low educational status with an average of 10 years of experience in cassava flour processing. Most of the respondents (67.8\%) engaged in cassava flour production as their main occupation and all (100\%) of them carried out fermentation of cassava tubers between 2-3 days, and sundry it within 3-4 days. The gross margin technique showed that in every one naira (N) invested on cassava flour production, 35 kobo is gained by each cassava processor. Hence, cassava flour production in the study area is profitable. Age (5\%), educational level (5\%), involvement in associations $(10 \%)$ and the cost of cassava tuber $(1 \%)$ are the key variables influencing the amount of revenue earned from cassava flour production. In conclusion, cassava flour production has the potentials of reducing food insecurity problem in Nigeria due to its profitability and as well contribution to people livelihood sustainability.
\end{abstract}

Keywords: Cassava Flour, Cassava Tubers, Women, Food Insecurity, Osun, Nigeria

\section{Introduction}

Women play a pivotal role in African agriculture. They act as producers, processors and marketers of some agricultural food products. Recently, the contribution of women in agricultural production has been noticed and extensively researched [5]. The position and role of women in Africa's agricultural production, and the circumstances under which they are forced to operate are not well understood and appreciated [2]. However, in view of the essential roles demonstrated by the rural women towards agricultural activities, a number of programs were initiated in order to boost their morale towards farm business participation. Few of the programs are Women in
Agriculture (WIA), Better Life Programme (BLP), Family Economic Advancement Programme (FEAP) and Family Support Programme (FSP).

All the programmes serves as mechanisms for giving women better, cheaper or more reliable access to land, credits, agricultural inputs, extension information and other resources. For instance, the WIA programme in the Agricultural Development Programs (ADPs) formed several cassava processing, utilization groups and promoted the use of improved technologies by working with the Rural AgroIndustrial Development Scheme (RAIDS) to improve awareness on existing processing facilities. The WIA units 
also attempt to secure and make available to women's groups improved cassava processing machines like vibrating sieve, mechanical peeler, motorized grater, motorized drier, screw jack, hydraulic press to increase processing efficiency and as well maximize profit [8].

Cassava is a root tuber being cultivated in rainforest and derived savannah zones of Nigeria. It is one of the most important staple food crops in sub-Saharan Africa, and its average consumption exceeds $300 \mathrm{~kg}$ per person annually in some areas of Africa [9]. It therefore worthy note that cassava flour production is one of the major entrepreneurial activities of rural women in Nigeria. They demonstrate a significant role in all stages of cassava flour (elubo-lafun) production, starting from processing, branding, packaging as well as marketing. In the processing of cassava products it is observed that more than $50 \%$ of the production was carried out by the women while the men only made their contribution during land preparation [6]. Cassava tuber is normally processed before eaten. It is usually subjected to different processing methods that aimed at reducing toxicity, improving palatability and converting the perishable fresh roots into stable products like Gari, Fufu and Lafun. Lafun is one of the major products obtained from cassava tubers, and it is known as the life saver of the poor or the 'poverty-alleviation food item' because it is cheap, easy to prepare and eat with any kind of soup. Small quantity is sufficient to feed household members due to its high carbohydrate content.

An average Nigerian meets about $95 \%$ of the minimum energy requirements from cereal and tuber crops, followed by grain legumes. Cereals constitute the highest variety of food produced in the northern zone of the country while roots and tubers constitute the major food crop in the south central zone of Nigeria. Current studies indicates that only cassava and yam among all others food crops are producing at a level of comparative advantage in Nigeria. It is Cassava is a carbohydrate food with low protein and fat. It is a major food crop and a cheap source of calorie, supplying about $70 \%$ of the daily calorie of over 50 million people in Nigeria [10]. It has also been estimated that cassava provides food for over 500 million people in the world [1].

Cassava is processed into various products such as cassava flour (lafun), cassava flakes (gari), cassava dough ( $f u f u$ and pupuru) and cassava starch [8]. Cassava flour (Lafun) is a common staple food in the South-West (Osun, Oyo, Ogun and Ondo state) and the South-East (Enugu, Calabar) and other states in Nigeria. Thus, the growth and sustenance of cassava flour (lafun) processing industries among women will be a factor for solving the food insecurity as well as alleviating poverty in Nigeria.

The roles of cassava flour in socio-economic development contribute to the economic development through the provision of food stuff for the ever increasing population particularly that of urban centers. Cassava flour can be stored to prevent spoilage and wastage which may later be consumed domestically or exported to increase the nation's exchange earnings. In essence, cassava flour processing industries have contributed to the economic development in the following ways: food processing to bring foreign exchange, provision of raw materials for industries, provision of employment opportunities, eradicating poverty and food insecurity in the rural areas and increase in the social responsibilities of entrepreneurs.

In view of these, this research work is designed to provide solutions to the following questions: What are the socioeconomic characteristics of cassava flour (Lafun) processors in Osun state? What are the inputs employed in transforming cassava tubers into cassava flour? What are the factors influencing the cassava flour production in the study area? What are the costs and returns to cassava flour making in the area? What are the problems militating against cassava flour processing in the area?

This study estimated economic implication of cassava flour processing among rural women in the Osun state, specifically it identified the socio-economic characteristics of the respondents, analyses the determinants of cassava flour production, determines the cost and returns of cassava flour production in the area and identify the problems encountered by the respondents during production activities in Boripe Local Government Area of Osun state, Nigeria.

\section{Methodology}

\subsection{Study Area, Population and Sampling Procedure}

This study was carried out in Boripe Local Government Area of Osun State. The Local Government Area is one of the thirty local governments in the state with its headquarters at Iragbiji. The local government area consists of twelve wards with major areas being Iree, Ada, Ororuwo, Aagba, Oore, Egbeda, Popo, Oloti which embodied many villages and hamlets. It is bounded to the north by Ifelodun local government, in the south by Obokun local government, in the west by Olorunda local government, and in the east by Boluwaduro local government. The inhabitants of Boripe local government are predominantly farmers and civil servants, some are also engaging in other occupations like trading, welding, tailoring, carpentry, brick layering fashion designing and a host of others are artisan. There are several markets to sell lafun within the study area such as Anaye market in Iragbiji, Ada market in Ada Township, Araro market in Iragbiji and a host of other markets in the area.

The vegetation of Boripe local government allows the cultivation of arable crops (such as cassava, maize, cowpea, yam, potato, millet) and tree crops (such as cocoa, kolanut, oil palm, and citrus). Other crops like banana, plantain, and vegetables are also grown mainly for consumption and marketing purposes. The population of this study comprises all the cassava flour (lafun) producers (women) in the study area. A multistage sampling technique was used to select the appropriate number of respondents for this study. The procedure involves a random selection of one Local Government Area, and from the Local Government Area, 
three (3) wards were randomly selected. Also, from each of the wards, five (5) villages were picked and 10 respondents were sampled from each of the villages which equate to 150 respondents altogether, but only 146 sample size was finally used for the analysis.

\subsection{Source of Data and Data Analysis}

Primary data were used for this study. Data were collected by the use of well-structured questionnaire, questions were designed to collect information on socio-economic characteristics of respondents, source of raw material (tubers and water), cost and returns, credit, storage and other problems faced the respondents in cassava flour making. The two variables involved in the study are the dependent and independent variables. The dependent variable for this study is the revenue generated in naira by the respondents (women) from cassava flour production and the independent variables are quantity of labour used, tons of cassava tubers processed, year of processing experience, age, year of formal education, cost of cassava tubers et cetera. Both descriptive and inferential statistics were used to analyse the data, the socioeconomic characteristics of respondents were described using descriptive statistics while the factors that determined the cassava flour making in the study area were analysed with multiple regression model. Also, gross margin technique was used to determine the profitability of cassava flour production in the study area.

\subsubsection{Multiple Regression Model}

The regression model was specified as shown below;

$$
\mathrm{Y}=\beta_{0}+\beta_{\mathrm{i}} \mathrm{X}_{\mathrm{i}}+\mu
$$

Where $\mathrm{Y}=$ total revenue generated from cassava flour (lafun) making ( $), \beta_{0}=$ constant term, $\beta_{i}=$ coefficient of $i^{\text {th }}$ independent variable, $X_{i}=$ vector of the independent variables: quantity of labour used $\left(\mathrm{X}_{1}\right)$, tons of tubers processed $\left(\mathrm{X}_{2}\right)$, years of processing experience $\left(\mathrm{X}_{3}\right)$, age $\left(\mathrm{X}_{4}\right)$, years of formal education $\left(\mathrm{X}_{5}\right)$, depreciated fixed cost $\left(\mathrm{X}_{6}\right)$, marital status $\left(\mathrm{X}_{7}\right)$, primary occupation $\left(\mathrm{X}_{8}\right)$, fermentation method $\left(\mathrm{X}_{9}\right)$, source of water used $\left(\mathrm{X}_{10}\right)$, source of credit $\left(\mathrm{X}_{11}\right)$ and cost of cassava tuber $\left(\mathrm{X}_{12}\right)$ and $\mu=$ error term.

\subsubsection{Gross Margin Technique}

Gross margin analysis was used to determine the profitability/net revenue of cassava flour making. The total cost incurred includes both the total fixed costs and total variable costs while the return is the revenue generated from the cassava flour production. The technique also indicated the benefit cost ratio (BCR) of cassava flour making enterprise. The gross margin was estimated by;

$$
\mathrm{GM}=\mathrm{GR}-\mathrm{TVC} ; \mathrm{NR}=\mathrm{GR}-\mathrm{TFC}
$$

Where; GR is gross revenue ( $\mathrm{N}), \mathrm{NR}$ is net revenue ( $)$, TC is total cost ( $)$, TFC is total fixed cost ( $)$ and TVC is total variable cost $(\mathrm{N})$.

\section{Results and Discussion}

\subsection{Socio-Economic Characteristics of the Cassava Flour-Lafun Processors}

The descriptive analysis of socioeconomic characteristics of cassava flour-lafun processors is presented in the table 1 below. From the table it showed that $37.8 \%$ of the respondents were between the ages of $31-40$ years, $32.3 \%$ of them were also between $41-50$ years old, while $30.2 \%$ of them were fallen between the ages of 51-60 years. It was revealed that $82.2 \%$ of the respondents were married, while the rest $(17.8 \%)$ were not married and they either single or separated. More than the average $(54.1 \%)$ of them have household size ranges between $5-7$ people and $41.8 \%$ of the respondents had household size ranging from $1-4$ people while very few $(4.1 \%)$ of them had household size of 8-10 people.

The result also showed that $34.2 \%$ of the respondents had primary education, $32.2 \%$ of the respondents had no formal education, $24.7 \%$ of them had secondary education, while $5.5 \%$ of them had adult education and only $3.4 \%$ had tertiary education, this finding generally indicated that the respondents are of low educational status in the study area. Years of experience in lafun making of 6-10 years accounted for $50.6 \%$ of the respondents, followed by $11-15$ years of experience with $24.1 \%$ of them, $15.7 \%$ of the respondents had 1-5 years of processing experience, and 9.7\% had $16-20$ years of processing experience. Almost (95.9\%) of the respondents were not involved in any association while the rest $(4.1 \%)$ of them were involved in processors' association. Most of the respondents $(67.8 \%)$ involved in cassava flour lafun production as their main occupation while $32.2 \%$ of them diversified into some other activities in the study area.

Table 1. Socio-economic Characteristics of the Cassava flour-Lafun Processors.

\begin{tabular}{lll}
\hline Socio-economic variables & Frequency & Percentage \\
\hline Age (years) & & \\
$31-40$ & 55 & 37.8 \\
$41-50$ & 47 & 32.3 \\
$51-60$ & 44 & 30.2 \\
Marital status & & \\
Married & 120 & 82.2 \\
Non-married & 26 & 17.8 \\
Educational level & & \\
No formal education & 47 & 32.2 \\
Adult education & 8 & 5.5 \\
Primary education & 50 & 34.2 \\
Secondary education & 36 & 24.7 \\
Tertiary education & 5 & 3.4 \\
Household size & & \\
$1-4$ & 61 & 41.1 \\
$5-7$ & 79 & 54.1 \\
$8-10$ & 6 & 4.1 \\
Years of experience & & \\
1-5 & 23 & 15.7 \\
6-10 & 74 & 50.6 \\
11-15 & 35 & 24.1 \\
16-20 & 14 & 9.7 \\
Membership of association & & \\
Yes & 6 & 95.9 \\
No & 140 & \\
\hline
\end{tabular}




\begin{tabular}{lll}
\hline Socio-economic variables & Frequency & Percentage \\
\hline Major occupation & & \\
Lafun processing & 99 & 67.8 \\
Not Lafun processing & 47 & 32.2 \\
Total & 146 & 100.00 \\
\hline
\end{tabular}

Source: Field survey, 2013

\subsection{Resources used in Cassava Flour Processing}

The result shows that $44.5 \%$ of the respondents utilized their family labour, while $30.1 \%$ of them make used of hired labour and $25.4 \%$ of the respondents employed both family and hired labour. It means that many of their respondents make used of their family labour to reduce the costs of production. The findings revealed that $56.2 \%$ of the respondents finance their business themselves, while $41.7 \%$ of them obtain loan from cooperative societies and $2.1 \%$ got theirs from bank loan implying that more than the average of them obtain their capital from personal savings. This finding corroborated with the findings by [3].

It was also showed that the larger percentage, (67.1\%) of the respondents got their cassava tubers from purchase market while the rest $(32.9 \%)$ of the respondents obtain their raw materials from their own farms and farm gate. It indicates that many of the lafun processors relied on purchased raw cassava tubers and it is in line with the result of [2]. The study also showed that majority of the respondents, $(80.8 \%)$ used well water, while $19.2 \%$ of them fetched water from stream or dam which are utilizing for soaking the raw cassava tubers in the earthen or plastic pot/bowl and concrete constructed in the production site.

Table 2. Distribution of Respondents by Resources used in Cassava Flour Processing.

\begin{tabular}{lll}
\hline Production Inputs & Frequency & Percentage (\%) \\
\hline Source of labour & & \\
Hired labour & 65 & 44.5 \\
Family labour & 44 & 30.1 \\
Hired and family & 37 & 25.4 \\
Source of credit & & \\
Self finance & 82 & 56.2 \\
Bank loans & 6 & 2.1 \\
Cooperative society & 61 & 41.8 \\
Source of cassava tuber & & \\
self & 48 & 32.9 \\
market & 98 & 67.1 \\
Source of water used & & 80.8 \\
Well water & 118 & 19.2 \\
Stream/dam water & 28 & \\
Total & 146 & 100.00 \\
\hline
\end{tabular}

Source: Field survey, 2013.

\subsection{Mode of Processing, Fermentation and Drying Periods of Cassava Flour}

The Table 3 shows the method of processing employed by the cassava flour producers in their production processes. It showed that every single respondent makes used of local method of processing in the study area and none of them use semi-modern and modern methods. This finding agreed with the study by [4] but it was not consistent with the result of [3] who observed that semi-modern method of processing was the most popular in comparison to other methods. The result shows that all $(100 \%)$ of the respondents soaked the cassava tubers within 2 - 3 days for fermentation. It means that at least 2-3 days is enough for cassava tubers to be fermented and ready for drying. The result revealed that $100 \%$ of the respondents carried out the drying for at least 3 days, it ascertained that all the processors will put their lafun under the high sun intensity for not less than 3 days after fermentation in order to ensure complete removal of moisture.

Table 3. Distribution of Respondents According to Method used, Fermentation Period and Sun Drying Days.

\begin{tabular}{lll}
\hline $\begin{array}{l}\text { Processing method } \\
\text { (local method) }\end{array}$ & $\begin{array}{l}\text { Fermentation period } \\
\text { (two-three days ) }\end{array}$ & $\begin{array}{l}\text { Sun drying period } \\
\text { (three days) }\end{array}$ \\
\hline $146(100)$ & $146(100)$ & $146(100)$ \\
\hline
\end{tabular}

Source: Field Survey, 2013

\subsection{Mode of Marketing, Sale and Profit Periods}

The findings revealed that $97.9 \%$ of the respondents sold their produce (cassava flour) to middle men while the remaining $(2.1 \%)$ sold cassava flour to the local restaurants. It implies that the respondents produce the cassava flour in large quantities and they were able to sell for wholesalers and retailers who then sell for individual households. The result in Table 4 shows that $61.1 \%$ of the respondents experienced highest sale during late raining season, while $39.0 \%$ believed that highest sale is during the dry season. It indicates that the cassava flour processors experienced the highest demand for their produce during late raining season. Over average $(55.5 \%)$ of the respondents obtained maximum profit during the late raining season while $39.0 \%$ also received maximum profit in the dry season and the rest $(5.5 \%)$ of them obtain their maximum profit during early raining season.

Table 4. Distribution of Respondents According to Marketing Mode, Sale and Profit Periods.

\begin{tabular}{lll}
\hline Transaction information & Frequency & Percentage (\%) \\
\hline $\begin{array}{l}\text { Mode of marketing } \\
\text { Middlemen }\end{array}$ & 143 & 97.9 \\
Local restaurants & 3 & 2.1 \\
Sale periods & & \\
Late raining season & 89 & 61.0 \\
Dry season & 57 & 39.0 \\
Profit making & & \\
Early raining season & 8 & 5.5 \\
Late raining season & 81 & 55.5 \\
Dry season period & 57 & 39.0 \\
Total & 146 & 100.0 \\
\hline
\end{tabular}

Source: Field Survey, 2013

\subsection{Problems Faced by the Cassava Flour Processors in the Study Area}

The result in the table below shows the problems encountered by the respondents during their processing activities. A multiple response was employed in which $82.2 \%$ of the respondents were 
confronted with financial problem, $81.5 \%$ of them were faced with equipment problem, while $56.8 \%$ of the respondents encountered unstable labour use and $61.0 \%$ of them were faced with problem of transportation due to cost and bad roads.

Table 5. Distribution of Respondents According to Problems Faced.

\begin{tabular}{lll}
\hline Problems faced & "Frequency & Percentage (\%) \\
\hline Finance & 120 & 82.2 \\
Equipment & 119 & 81.5 \\
Labour instability & 83 & 56.8 \\
Transportation cost & 89 & 61.0 \\
\hline
\end{tabular}

Source: Field Survey, 2013. "Multiple responses

\subsection{Result of Gross Margin Estimation on Cassava Flour Processing}

The gross margin on cassava flour making was computed to determine its profitability among the respondents in the study area. The result shows that the total cost incurred per month was 147509.5890 and the total revenue generated was 211463.1507 with the profit by given the difference between the total revenue TR and total costs TC in naira. Thus, Profit $=$ Total revenue - Total cost $=\$ 211463.1507$ $\$ 147509.5890=\$ 63,953.56$. This indicates that the profit earned per month by individual cassava flour producer will be $\$ 63,953.56$. In addition, for this study the benefit-cost ratio $(\mathrm{BCR})$ of 1.35 was obtained as shown below:

$$
\begin{gathered}
\mathrm{BCR}=\text { Total revenue }(\mathrm{N})=\mathrm{N} 211463.1507=1.35 \\
\text { Total cost }(\mathrm{N}) \mathrm{147509.5890}
\end{gathered}
$$

The implication of this result is that for every 1.00 invested on the cassava flour production, $1.35 \mathrm{kobo}$ is returned. This signifies that the enterprise is worthwhile; hence the cassava flour processors are encouraged to invest more in the business.

\subsection{Factors Determining the Total Revenue Made by Cassava Flour Processors-A Multiple Linear Regression}

The linear function was selected as the lead equation in table 6 because it gave the highest adjusted $R^{2}$ value and the maximum number of significant variables than the other functional forms. The linear regression analysis shows the relationship between the value of the total revenue of Lafun processors which is the dependent variable and the explanatory variables. The value of the adjusted $R^{2}(0.991)$ obtained indicates that about $99.1 \%$ observed variation in the revenue of the respondents is explained by the association between the independent variables.

The result reveals that the cost of cassava tuber, age of respondent, educational level, and involvement in associations represent the significant variables in the model. The cost of cassava tuber has a positive coefficient and significantly determines the revenue generated from the cassava flour making. This finding implies that increase in cost of cassava tubers would lead to increase in revenue accrued to respondent. This may be because of the increase in income as result of more revenue generated from the enterprise chase the available quantity of cassava tubers present in the farm, thus cause the hike in the price of cassava tubers. It clearly means that the more the income, the more the demand for raw cassava tubers.

The coefficient of age of respondent is statistically significant at 5\% level and as well positively related to revenue generated from Lafun processing enterprise. It indicates that an increase in the age of women cassava flour processors will also increase the profit made from the enterprise. This is an indication that cassava flour processing can be feasibly carried out among the women cut across all ages, since it is a less energy utilization business and even their age will add to the experience in the process of profit making.

The level of education is significant and has a direct relationship with the amount of revenue obtained from the enterprise. This reflects that the educational status of the respondents will enlighten them on the business by increasing their exposure/knowledge about the product ability in yielding huge revenue. Involvement in associations shows negative influence on the revenue generated from lafun processing enterprise. Briefly, it an implication that increase membership in associations, will decrease the actual amount of revenue/profit obtained from the enterprise. This may be due to the fact that too much of associational memberships distort the concentration of respondents on their business and then lower quantity produced which in turn reduce revenue. Meanwhile, all other explanatory variables like year of experience and processing costs are insignificant or intangible as regard the cassava flour (lafun) production among the women in the study area.

Table 6. Analysis of Factors Determining the Total Revenue Generated by the Respondents.

\begin{tabular}{llll}
\hline Explanatory Variables & Coefficients & T-values & $\begin{array}{l}\text { Significance } \\
\text { Levels }\end{array}$ \\
\hline Constant term & -21063.571 & 0.0000 & \\
Cost of cassava tuber & 1.422 & $60.103^{* * *}$ & Significant \\
Cost of peeling (N) & 0.449 & 0.864 & Not significant \\
Cost of soaking (N) & 0.625 & 0.519 & Not significant \\
Cost of drying (N) & -0.028 & -0.017 & Not significant \\
Age of respondent $(\mathrm{yr})$ & 431.5 & $2.165^{* *}$ & Significant \\
Educational level & 2262.8 & $2.469^{* *}$ & Significant \\
Year of experience $(\mathrm{yr})$ & 280.7 & -0.873 & Not significant \\
Involve in association. & -6200.1 & $-1.373^{*}$ & Significant \\
Adjusted $\mathrm{R}^{2}=0.991 \rightarrow(99.1 \%)$. & & \\
\hline
\end{tabular}

Source: Field Survey, 2013

\section{Conclusion and Recommendations}

The study pointed out that most of the respondents were still at middle-age group and as well engaged in cassava flour (lafun) production as their main occupation with more than half $(50.6 \%)$ had up to $6-10$ years of experience. Majority $(82.2 \%)$ of the women cassava flour processors were married and $54.1 \%$ of the respondents also have household size of 5-7 people. Very few $(3.4 \%)$ attended tertiary institution and 
majority of them have primary and secondary education in the study area. The result of cost and return estimation shows that in every one naira ( invested on cassava flour production 35 kobo is gained by each cassava flour processor hence, cassava flour (lafun) production in the study area is profitable.

The regression analysis reveals that age of respondent, educational level, involvement in association and cost of cassava tuber were significant variables which determine the total revenue generated from the cassava flour production. On the basis of this study, the major problems faced by the respondents in the study area include labour instability, lack of finance, and cost of transportation as well as improved equipment not made available at their disposal. The study therefore concludes that a large number of women who are under working age should be encouraged to invest in processing cassava flour (lafun). This will help them to sustain their livelihood because the enterprise is less strenuous, not much capital intensive and also profitable.

The study recommended that the women should have easy access to credits to facilitate their businesses rather than depend on personal savings as the only source of finance. They should also form cooperative groups of cassava flour (lafun) production association as membership in association is one of the significant variables. There should be more enlightenment programme on the importance of education as it affects the level of cassava flour production in the study area. The cost of procuring cassava tuber should be lowered in order to increase the level production and subsequently increase profitability.

\section{References}

[1] Abu, J. O; Badifu, G. I. O. and Akpapunan, M. A. (2006). Effect of crude palm-oil inclusion on some physic-chemical properties of gari, a fermented cassava food product. Journal of Food Science and Technology vol. 24: 73-79.
[2] Adeniyi A. B, Daud A. S, Amao O and Omotayo A. O (2016). Determinants of Rural Women's Livelihood in Ibarapa North Local Government Area of Oyo State, Nigeria. J Hum Ecol, $56(1,2): 84-90$.

[3] Ashaye, O. A, Adegbulugbe, T. A and Dawodu, O. J (2005). Evaluation of the Processing Technologies of Cassava Chips and Flour in Oyo and Ogun States of Nigeria. World Journal of Agricultural Sciences, 1 (1): 56-58.

[4] Bamidele, A. A. (2007). Economics of Cassava Flour Production in Odeda Local Government Area, Ogun State, Nigeria.

[5] Fakoya E. O; Agbonlahor, M. U. and Dipeolu, A. O. (2007): Attitude of Women Farmers towards Sustainable Land Management Practices in South-Western Nigeria. World Journal of Agricultural Sciences, 3 (4): 536-542.

[6] Mgbakor, M. and Nwamba, H. O. (2013). The Role of Women in Cassava Production in Awgu L. G. A, of Enugu State, Nigeria, American-Eurasian Journal of Agronomy 6 (1): 1924.

[7] Muhammad-Lawal, A; Omotesho, O. A. and Oyedemi, F. A. (2013). An Assessment of the Economics of Cassava Processing in Kwara State, Nigeria. International Conference of the African Association of Agricultural Economists, September 22-25, 2013, Hammamet, Tunisia.

[8] Odebode, Stella O. (2008). Appropriate Technology for Cassava Processing in Nigeria: User's Point of View. Journal of International Women's Studies, 9 (3), 269-286.

[9] Omotayo A. O and Oladejo A. J (2016). Profitability of Cassava-based Production Systems. J Hum Ecol, 56 (1, 2): 196-203.

[10] Oyewole, O. B. and Afolami, O. A. (2001). Quality and preference of different cassava varieties for 'lafun'production. Journal of Food Technology. 6: 27-29. 